Article

\title{
Historical Radial Growth of Chinese Torreya Trees and Adaptation to Climate Change
}

\author{
Xiongwen Chen 1 \\ Department of Biological \& Environmental Sciences, Alabama A \& M University, Normal, AL 35762, USA; \\ xiongwen.chen@aamu.edu
}

Received: 30 May 2020; Accepted: 29 June 2020; Published: 30 June 2020

check for updates

\begin{abstract}
Chinese Torreya is a vital crop tree with an average life span of a thousand years in subtropical China. Plantations of this tree are broadly under construction, to benefit the local economy. Information on the growth and adaptation to climate change for this species is limited, but tree rings might show responses to historical climate dynamics. In this study, six stem sections from Chinese Torreya trees between 60 and 90 years old were acquired and analyzed with local climate data. The results indicated that the accumulated radial growth increased linearly with time, even at the age of 90 years, and the average radial increment of each tree ranged from 1.9 to $5.1 \mathrm{~mm} /$ year. The variances of basal area increment (BAI) increased with time, and correlated with the variances of precipitation in the growing seasons. Taylor's power law was present in the radial growth, with the scaling exponents concentrated within 1.9-2.1. A "Triangle"-shaped relationship was found between the precipitation in the growing seasons and annual radial increments. Similar patterns also appeared for the standard precipitation index, maximum monthly air temperature and minimum monthly air temperature. The annual increases were highly correlated with the local climate. Slow growth, resilience to drought and multiple stems in one tree might help the tree species adapt to different climate conditions, with the implications for plantation management discussed in this paper.
\end{abstract}

Keywords: basal area increment; air temperature; precipitation; Taylor's power law; tree ring analysis

\section{Introduction}

Progressing global climate change, with increased frequency of extreme climatic events, increased atmospheric $\mathrm{CO}_{2}$ concentration and related disturbance regimes, affects plant growth, survival, and range shift [1,2], which causes environmental and economic consequences [3,4]. Increasing air temperature will accelerate plant growth and increase the rate of water use; increasing atmospheric $\mathrm{CO}_{2}$ concentration will decrease leaf stomatal conductance and lead to increased water-use efficiency, but this effect will vary with species, and will depend on soil water and nutrient status $[5,6]$. In order to mitigate the negative impacts of climate change on plant production and maintain sustainable food supplies, it is necessary to develop adaptation strategies and enhance plant resilience, especially for those crucial crops [7]. Since climate change's impacts on plant production may have spatial and temporal variations, due to complicated interactions among species, weather and landscape [8], environment-specific or local adaptation strategies need to be developed $[9,10]$. Studying some existing plants (e.g., trees) with long life spans and already-experienced climate dynamics may help provide clues in understanding plant adaptation strategies [11].

Chinese Torreya (Torreya grandis cv Merrillii) is an evergreen coniferous tree with light green leaves in subtropical China [12,13]. Currently, there exist only six species, with a restricted distribution globally. T. california Torrey and T. taxifolia Arn. are distributed in North America [14], T. nucifera (L.) Sieb. et Zucc. is in Japan and South Korean [15], and three species (T. fargesii Franch, T. grandis Fort. ex Lind. and T. jackii Chun) and two varieties (T. fargesii var. yunnanensis and T. grandis var. 
jiulongshanensis) are found in China [13,16]. Only Chinese Torreya trees produce edible seeds, and can live for a thousand years $[13,17]$, with some dating to the late Tang Dynasty in China. This tree was first scientifically described by R. C. Ching in 1927 [18]. Chinese Torreya has become an important economic tree cultivar for its nuts, which have been used as food in China [19]. One mature tree can produce thousands of dollars in nut crops [20]. The economic benefit has helped thousands of farmers to overcome poverty in Shaoxing [21,22]. Currently, establishing Chinese Torreya plantations and providing nuts is a strategy for poverty alleviation in some poor mountainous areas. The tree also has important medicinal value [23]. Additionally, its timber is an excellent material for high-quality ornaments, such as sculptures and furniture. An increasing number of farmers are setting up Chinese Torreya plantations in order to gain a higher income from this high-value tree species. However, this tree grows slowly, usually producing seeds after 5-10 years [12,20]. This tree species experienced an increase in annual air temperature from $15^{\circ} \mathrm{C}$ to $17.5^{\circ} \mathrm{C}$ during the last century in this region [11]. Under the global climate change scenario, the annual air temperature and precipitation in this region are modeled to increase by about $2-2.5{ }^{\circ} \mathrm{C}$, and $2-12 \%$, respectively [24]. It is unknown whether climate change will affect this tree, and whether this species can adapt to climate change. Currently, there are some studies on the short-term physiological responses of Chinese Torreya seedlings under a controlled environment $[25,26]$. For one-year-old seedlings, the growth in height was found mainly in May-June and September [27]. However, there is limited information concerning long-term radial growth for mature trees of this critical species.

One approach to studying the tree growth process is through tree ring analysis, which provides an understanding of tree growth dynamics and the capacity to adapt to climate change [28]. Tree rings can be used to estimate tree age and assess long-term growth patterns in tree species, which provide information on species life history $[29,30]$. Tree ring widths can also give information about the growth, biomass accumulation and productivity of the species [31,32]. In addition, tree rings reflect the effect of climatic and environmental conditions on tree growth, and the vulnerability of tree species [33-36]. The patterns of tree rings show the combined impact of growth responses and environmental changes on tree species. Increasing atmospheric $\mathrm{CO}_{2}$ concentration can increase the photosynthetic rate, but this also depends on air temperature, water and nutrient condition. Climate change may lead to a reduction in rainfall but increased temperatures, which can affect some trees' growth and carbon sequestration potential $[37,38]$. The long life span of Chinese Torreya trees provides an opportunity to study its adaptation to climate dynamics. However, so far, there is no chronological study for Chinese Torreya.

Sustainable management of Chinese Torreya plantations needs to enhance seed production, carbon storage and livelihoods [12,20,39,40]. These objectives require a deeper understanding of the tree's growth behavior and responses to past environmental changes. However, it is challenging to acquire stem samples, because these trees have been the source of income for farmers, and it is not possible to collect samples without damaging the tree. Further, applying an increment borer can introduce diseases. Most old trees have a rotten heartwood, although they still grow well and produce seeds.

This study aims to find some tree samples and study tree rings of Chinese Torreya trees, as well as find their growth patterns. Since Chinese Torreya trees have existed in the region for more than a thousand years, it is reasonable to assume that this tree could endure climate change. Furthermore, it was found that there was an increase of inter-annual variation in seed production with time in some trees due, to environmental change [41]. Thus, it might be assumed that there was an increased inter-annual variation of tree ring growth for the Chinese Torreya. The specific objectives of this study include: (i) studying the growth rate and patterns of tree rings and testing the above assumptions; (ii) indicating relationships between tree growth and climate, and understanding the tree's adaptation; and (iii) providing suggestions for the adaptive management of Chinese Torreya forests under climate change. 


\section{Materials and methods}

\subsection{Materials}

Six stem sections from six Chinese Torreya trees were used for this study, and one tree (tree \#6) had two stems according to the two sets of tree rings (Table 1). All stem sections are preserved in the Torreya Museum at Zhuji County, in Zhejiang Province of China. Each stem section was acquired from the tree bottom (above the grafting point) in the nearby Chinese Torreya forest $\left(27.7191^{\circ} \mathrm{N}, 120.5127^{\circ} \mathrm{E}\right)$ at Zhaojiazhen around 2015. Trees of 100 years of age can usually reach $10-15 \mathrm{~m}$. These trees were cut down due to house building or wind damage. Tree \#5 might be a different ecotype or mutation. This area is the central production area of Chinese Torreya trees, and the oldest Chinese Torreya tree in

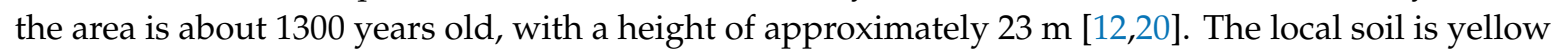
earth, with a $\mathrm{pH}$ value of 5.2-7.5. The elevation varies from about $300 \mathrm{~m}$ to $600 \mathrm{~m}$. The region has a monsoon climate with a hot and humid summer and relatively cold and wet winter. The annual mean temperature is approximately $16^{\circ} \mathrm{C}$, and the average annual precipitation is about $1400 \mathrm{~mm}$, which is mostly concentrated between May and August $[11,39,40]$. Intense rainfall usually occurs during the monsoon and typhoon periods, within the growing seasons. Currently, routine management practices include weeds control, tilling or fertilizer applying. However, there were limited management practices about 20 years ago, and it can thus be assumed that the growth of these sampled trees was mainly controlled by the natural condition. Since the ages of these trees were different, it is not valid to compare their tree rings directly because they might be at different life stages. However, comparing their growth patterns and general relationships with climate would be helpful to understand this tree species' adaptation to historical climate dynamics

Table 1. Tree ring information of six Chinese Torreya trees.

\begin{tabular}{cccccccc}
\hline Item & Tree \#1 & Tree \#2 & Tree \#3 & Tree \#4 & Tree \#5 & \multicolumn{2}{c}{ Tree \#6 } \\
\cline { 6 - 8 } & & & & & & Stem 1 & Stem 2 \\
\hline Age (year) & 90 & 89 & 81 & 86 & 63 & 75 & 80 \\
Diameter (mm) & 426 & 408 & 382 & 340 & 638 & 368 & 308 \\
$\begin{array}{c}\text { Average } \\
\text { Ring width (mm) }\end{array} \quad 2.4$ & 2.3 & 2.4 & 2.0 & 5.1 & 2.5 & 1.9 \\
$\begin{array}{c}\text { Maximum } \\
\text { Ring width (mm) }\end{array}$ & 5 & 5 & 9 & 7 & 8 & 8 & 7 \\
Minimum ring width (mm) & 0.5 & 1 & 0.5 & 0.3 & 1 & 1 & 1 \\
\hline
\end{tabular}

\subsection{Methods}

Tree ring measurement: For each stem section, the radiating rings were measured in three different directions because the tree rings were not perfect circles. Then, the average of the ring radiates, widths between rings or annual radial increments, and basal areas of increases (BAI) were estimated.

Taylor's power law: Taylor's power law is one of the most widely verified empirical relationships in ecology [42]. In this study, Taylor's power law is expressed as:

$$
\text { Variance }=a \times \text { Mean }^{r}
$$

where Variance is the variance of tree ring radiates, and the Mean is the average of tree ring radiators. After taking the logarithm, $\log ($ Variance $)=\log (a)+r \times \log ($ Mean $)$. With the time scale increased from 1,2 or 3 to the age of a tree, the scaling exponent $(r)$ between the variance and average of tree ring radiators for each Chinese Torreya tree was estimated.

Climate data: Since there was limited climate information from the ground observations in the area with Chinese Torreya plantation at Zhaojiazhen, the climate data for this area were collected from the Climate Research Unit. The high-resolution gridded $\left(0.5^{\circ} \times 0.5^{\circ}\right)$ data of the monthly air temperature and precipitation during 1923-2015 were used in this study. The data were drawn directly 
from the CRU TS 4.03 dataset and related nearby observations [43]. The CRU dataset has been broadly cross-checked with ground-monitored climate data [44]. Thus, here the data were not cross-checked due to the limited ground observations.

Each year, the average monthly air temperature, maximum and minimum monthly air temperature, and the average monthly air temperature during the growing season (from April to September) were estimated. Although Chinese Torreya is an evergreen tree species, it usually stops radial growth in wintertime.

The drought was estimated by the standardized precipitation index (SPI), which is based on [45], and only the precipitation was involved.

Monthly SPI = (Monthly precipitation - the average precipitation of this month from 1923 to 2015)/the standard deviation of this month's precipitation from 1923 to 2015 . If SPI > 0, it is wet; if SPI $<0$, it is dry.

SPI in the growing seasons = the sum of the monthly SPI from April to September each year.

Precipitation in the growing seasons $=$ the sum of the monthly precipitation from April to September each year.

Also, with the consideration of drought induced by heat in the growing seasons, the hydrothermal coefficient (HTC), including both air temperature and precipitation, was used here by applying Selyaninov's formula as the following [46]:

$$
H T C=\Sigma p /(\Sigma t \times 10)
$$

where $\Sigma p$ and $\Sigma t$ are the sum of precipitations and air temperatures $\left(\geq 10^{\circ} \mathrm{C}\right)$ in the growing seasons, respectively; when HTC > 1.0, it is considered humid; while HTC is within 0.7-1.0, it is dry; and if HTC is within $0.4-0.7$, it is very dry [46].

Statistics: Pearson's correlation was used between the accumulated radial growth and time, BAI and time, $\log$ (average of radial growth) and $\log$ (variance of radial growth), the slopes of the accumulated radial growth and the scaling exponents of Taylor's power law, SPI and HTC, and $\log$ (variance of precipitation) and $\log$ (variance of BAI) in the six trees. The correlation coefficients were recorded, and the statistical test was considered as significant at $p<0.05$.

\section{Results}

\subsection{Tree Age and Growth}

The tree ages based on the tree rings varied from approximately 63 to 90 years old, among the six trees considered under this study (Table 1). The average increment of tree rings for each tree ranged from $1.9 \mathrm{~mm}$ to $5.1 \mathrm{~mm}$. The maximum width of the tree rings was $9 \mathrm{~mm}$, and the minimum width was $0.3 \mathrm{~mm}$. The increments of radial growth were mainly distributed at 1 and $2 \mathrm{~mm}$. The variance of radial increments did not increase with time for all trees. However, the accumulated radial growth increased linearly with time for each tree (Figure 1), and most of them had slight changes in growth rate. For tree \#3, the growth rate changed around 41 years old. For tree \#6, the two stems had different rates of accumulated radial growth. The accumulated radial growth did not become stable for each tree, which means these trees were not senescent in their ages. BAI generally increased with tree, age but varied dramatically (Figure 2). The variance of BAI increased with time for all trees (Figure 3). 

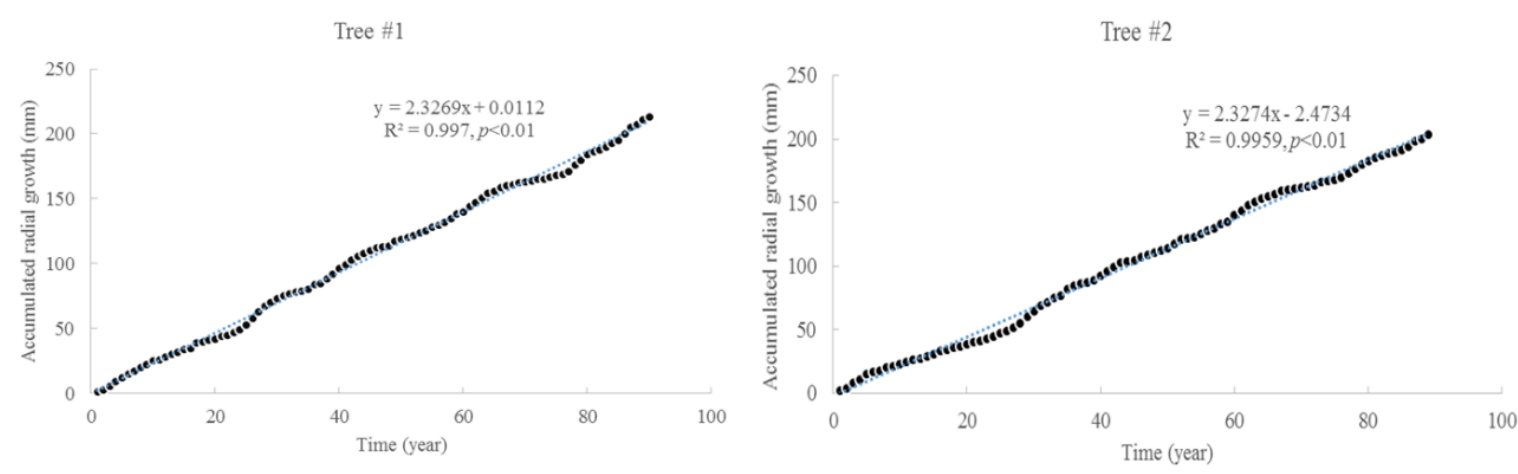

Tree \#3

Tree \#4
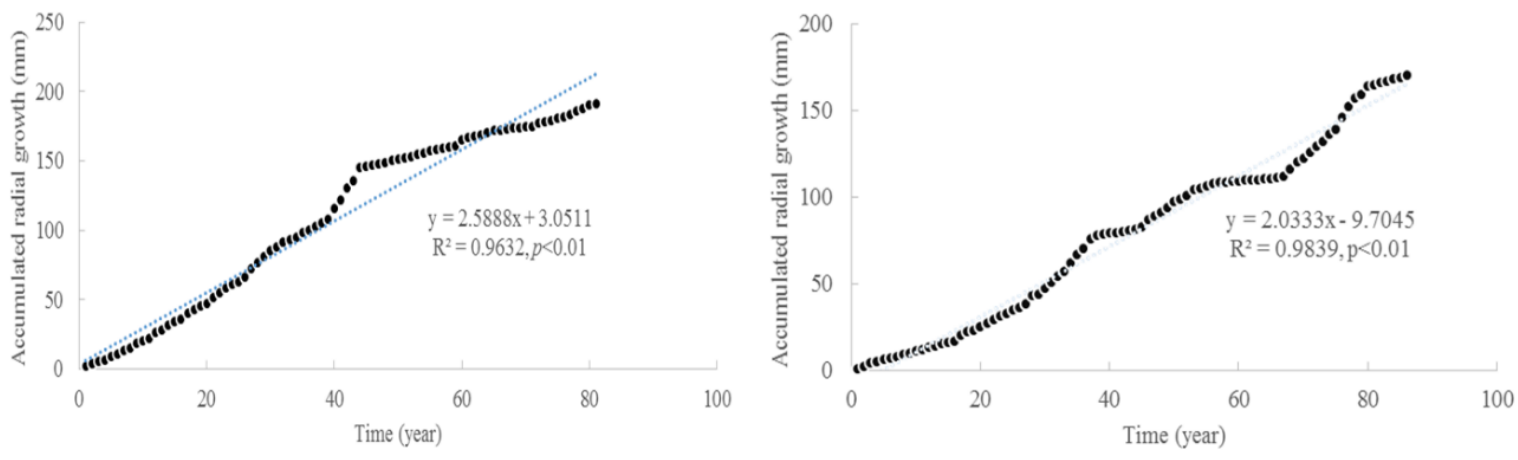

Tree \#5
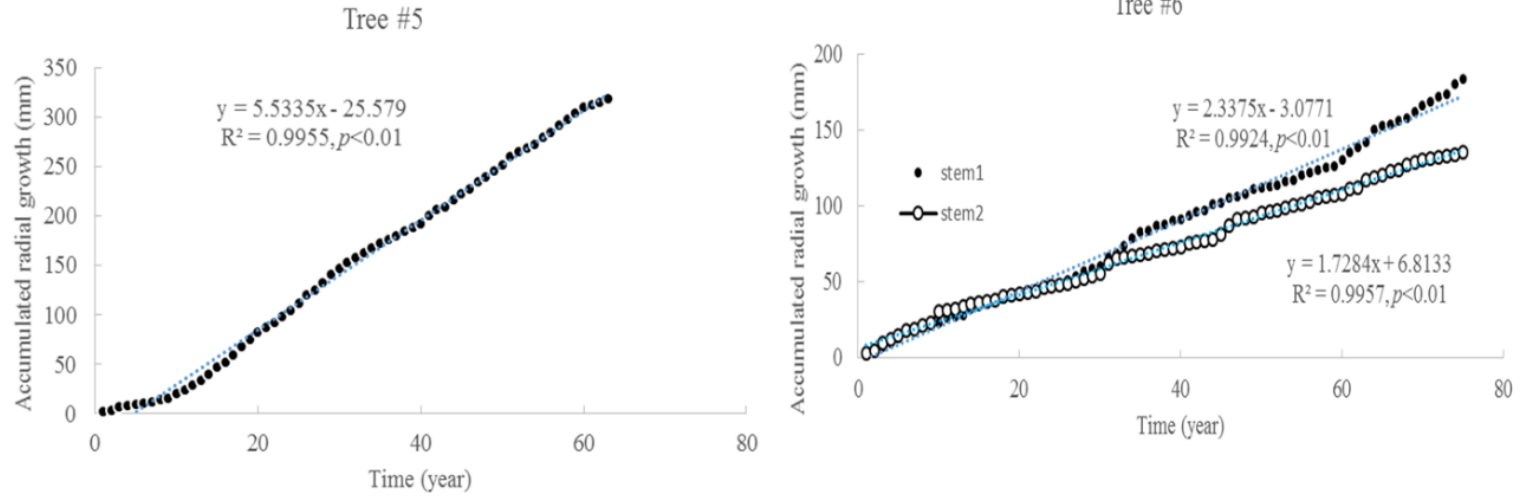

Figure 1. Accumulated radial growth with time for six Chinese Torreya trees.

\subsection{Taylor's Power Law}

Taylor's power law was present between the average accumulated radial growth and variance (Figure 4). The scaling exponents were concentrated within 1.9-2.1, which might indicate a similar growth regime. For tree \#6, the two stems had similar scaling exponents. These scaling exponents were significantly correlated with the slopes of the fitting lines between the accumulated radial growth and time (Figure 5). 
Tree \#1
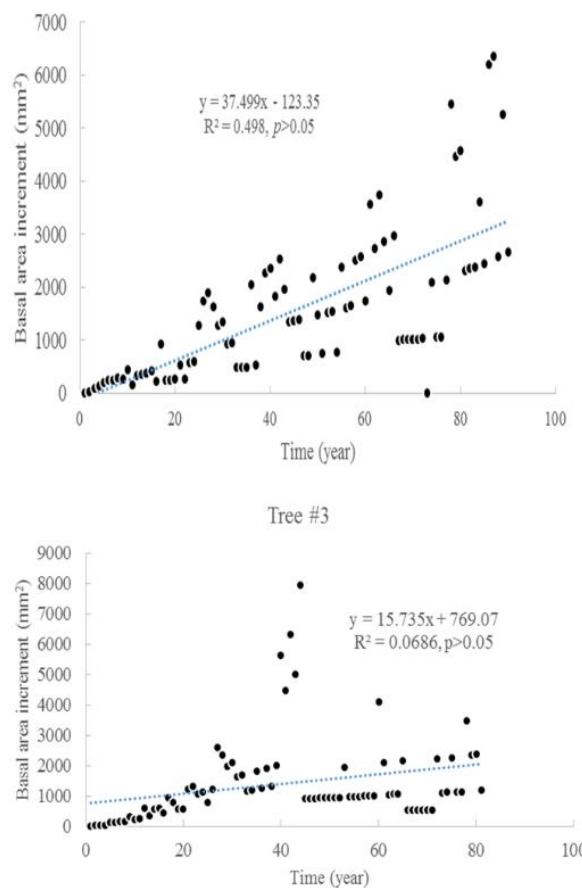

Tree $\$ 5$

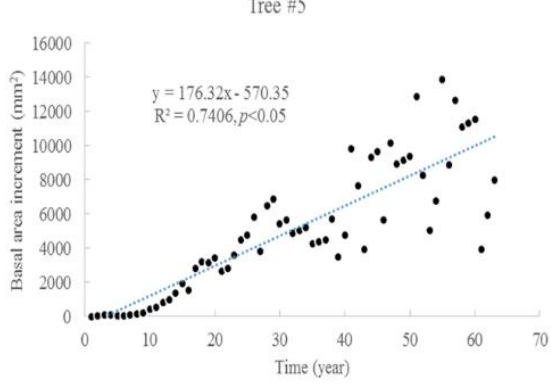

Tree \#2

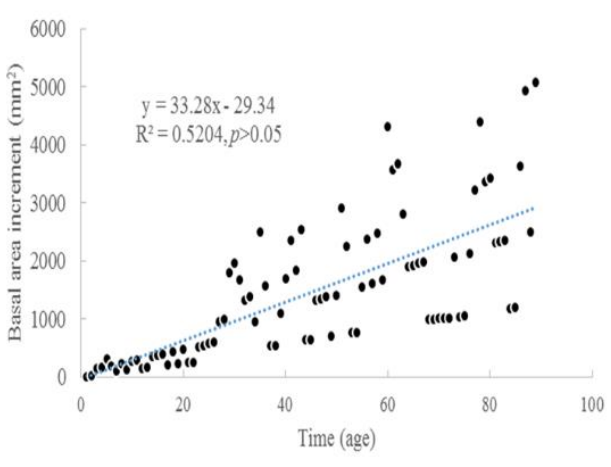

Tree \#4

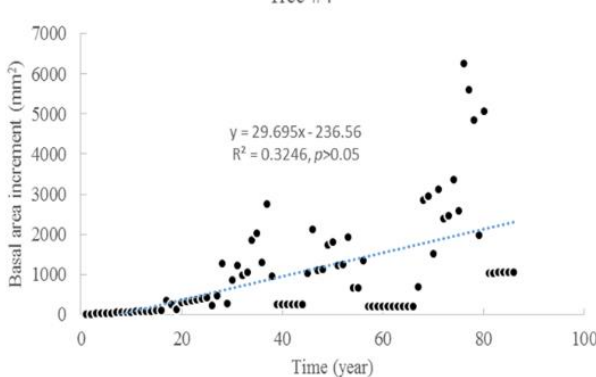

Tree \#6

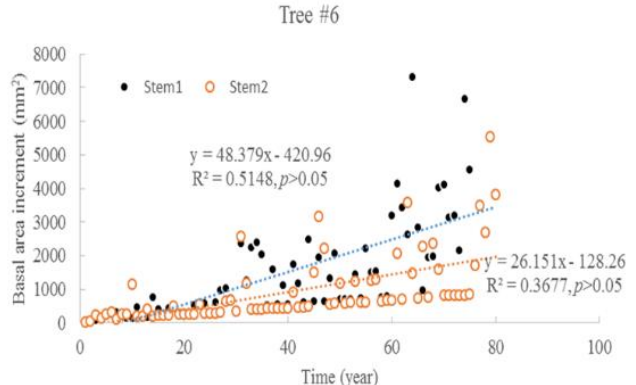

Figure 2. Basal area increments (BAI) change with time for six Chinese Torreya trees.

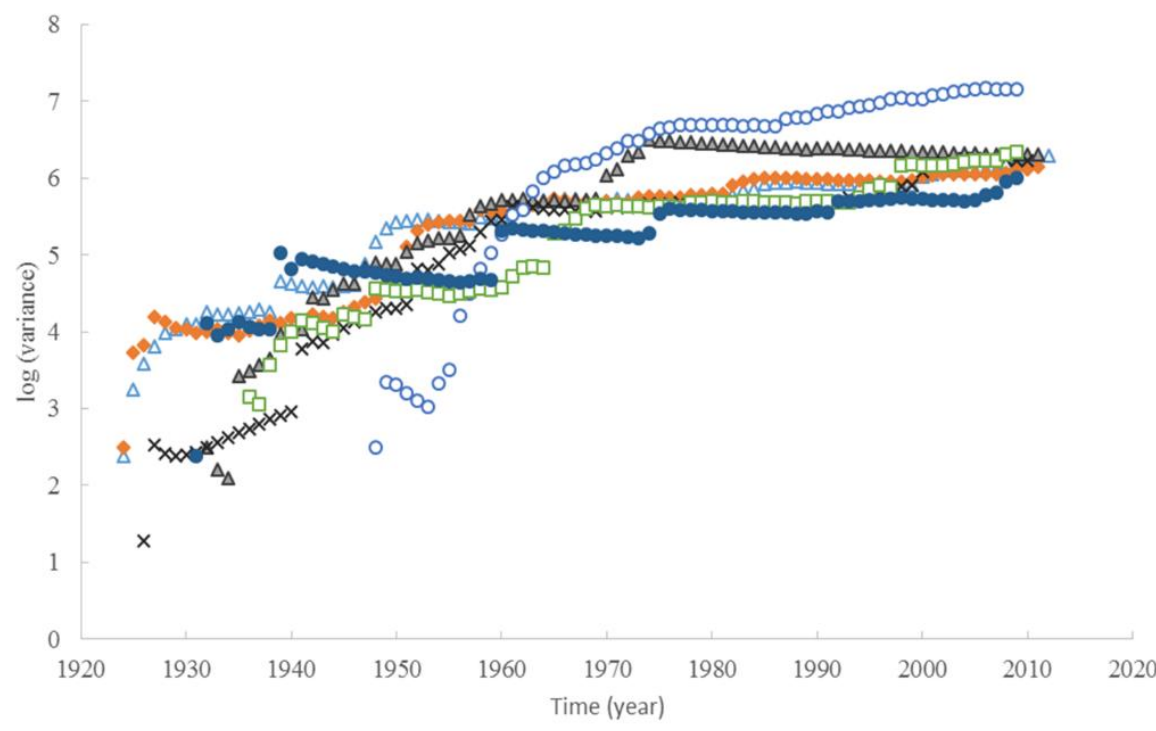

$\Delta$ Tree1 $\bullet$ Tree2 $\Delta$ Tree3 $\times$ Tree4 OTree5 $\square$ Tree6-1 $\bullet$ Tree6-2

Figure 3. The variance of BAI increased with time for six Chinese Torreya trees. 


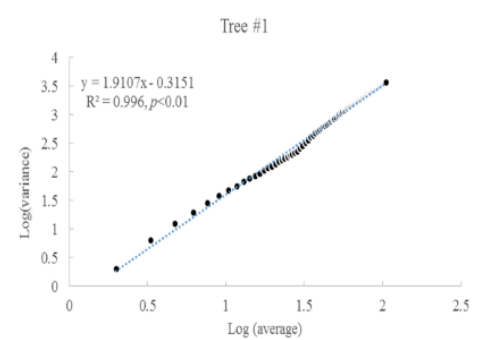

Tree \#3

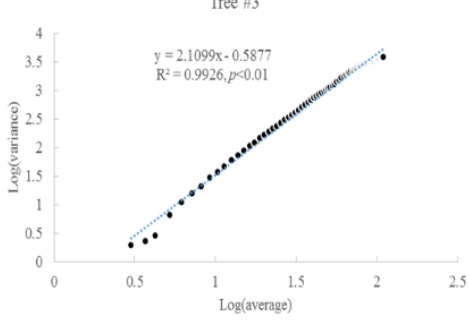

Tree \#5

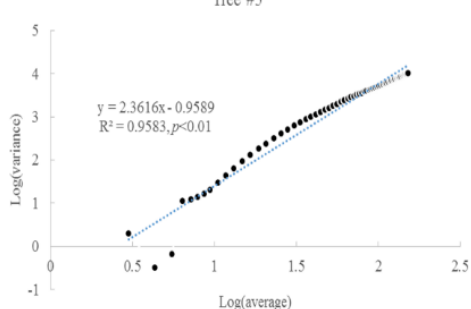

Tree \#6-stem 2

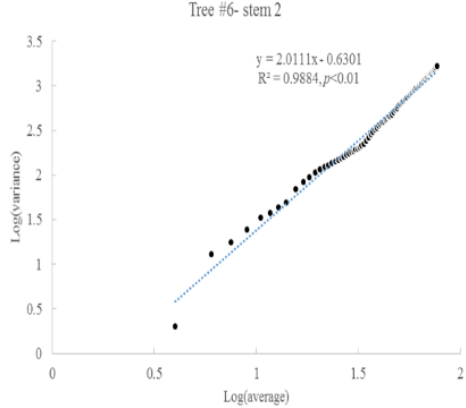

Figure 4. Taylor's power law in the radial growth for six Chinese Torreya trees.

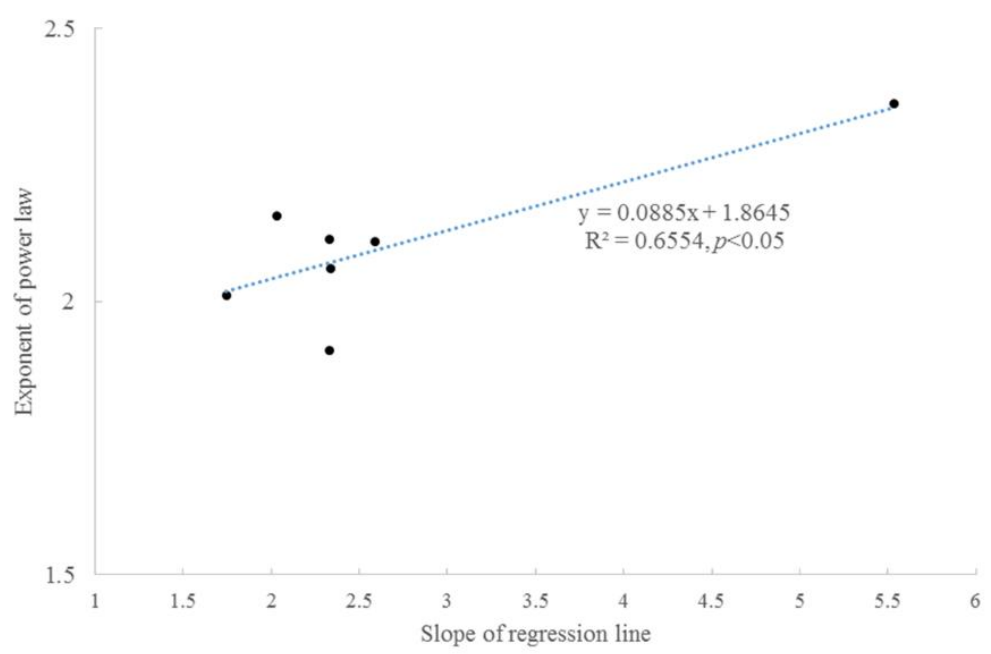

Figure 5. Correlation between the scaling exponents of Taylor's power law and the slopes of fitting lines between accumulated radial growth and time.
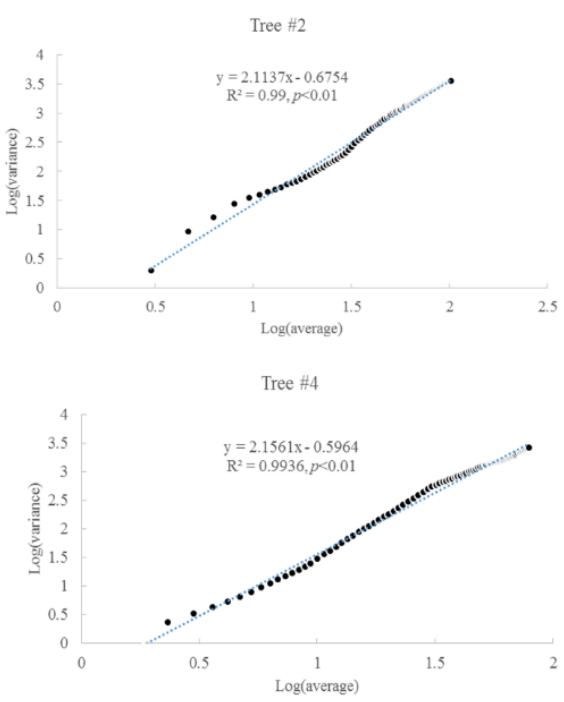

Tree \#6- stem 1
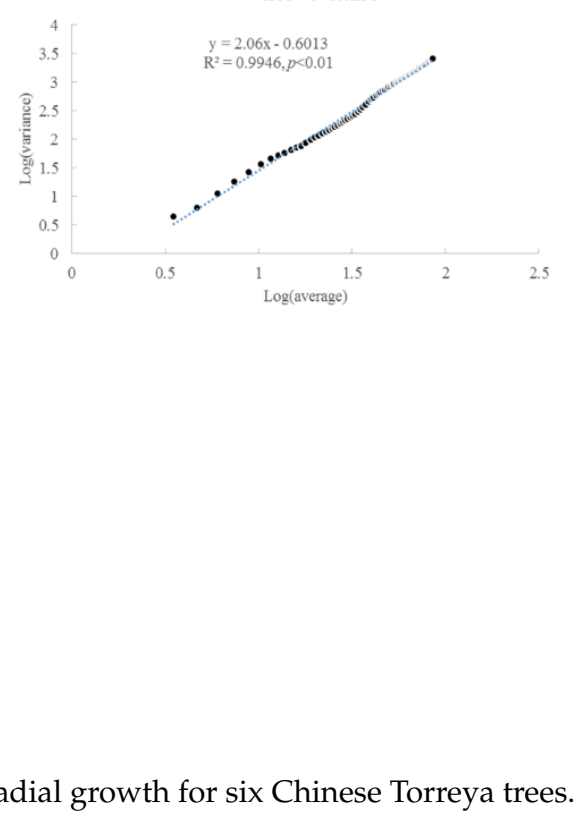


\subsection{Climate and Radial Growth}

The relationship between the average monthly air temperature during the growing season and annual radial increment was not apparent. A "Triangle"-shaped relationship existed between the precipitation in the growing seasons and annual increments. When the accumulated precipitation during the growing seasons was close to an average of $975 \mathrm{~mm}( \pm 200 \mathrm{~mm})$, there were high annual increments in radial growth (Figure 6). This pattern was similar to the SPI, which was between -2 and 2 (Figure 7). For the two stems of tree \#6, stem 1 had more growth when SPI $<0$, while stem 2 had more growth when SPI $>0$. The sensitivity and lasting time of each tree that responded to SPI change were different; for example, tree \#4 could grow at $0.3 \mathrm{~mm}$ each year for 10 years (Figure 8). Similar "triangle"-shaped patterns existed for the maximum monthly air temperature in the growing seasons or the minimum monthly air temperature in winters (Figure 9). When the maximum monthly air temperature was around $27.5-28.5^{\circ} \mathrm{C}$, or the winter monthly air temperature about $3-4{ }^{\circ} \mathrm{C}$, there were high annual increments in radial growth.

There was a significant correlation between SPI and HTC $(p<0.05$, Figure 10), which indicates the consistency between the two metrics. The trees had a high BAI when HTC was around 0.7-0.9, which was classified as a dry condition, based on HTC.
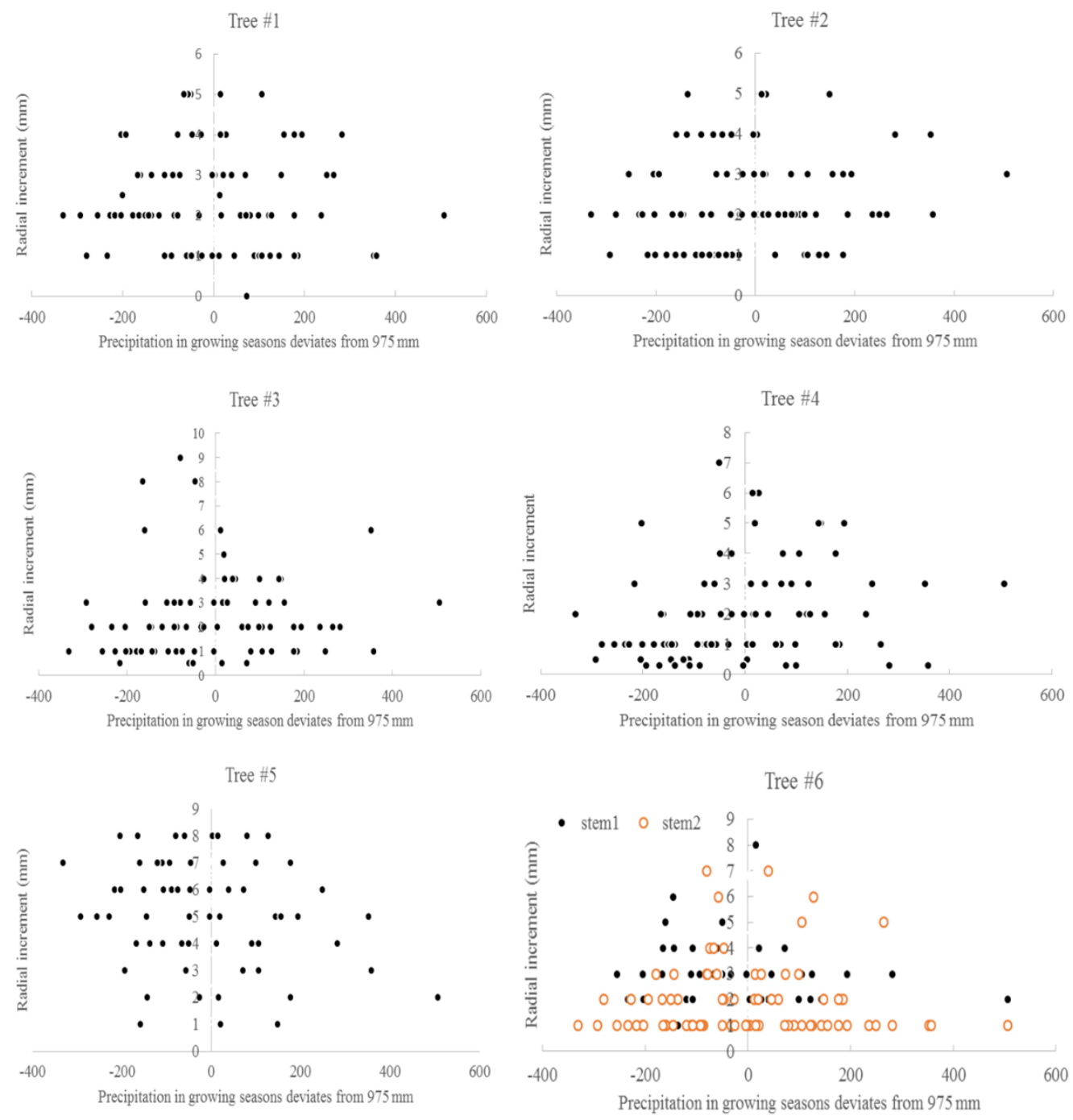

Figure 6. Precipitation in growing seasons and annual radial increments for six Chinese Torreya trees. 

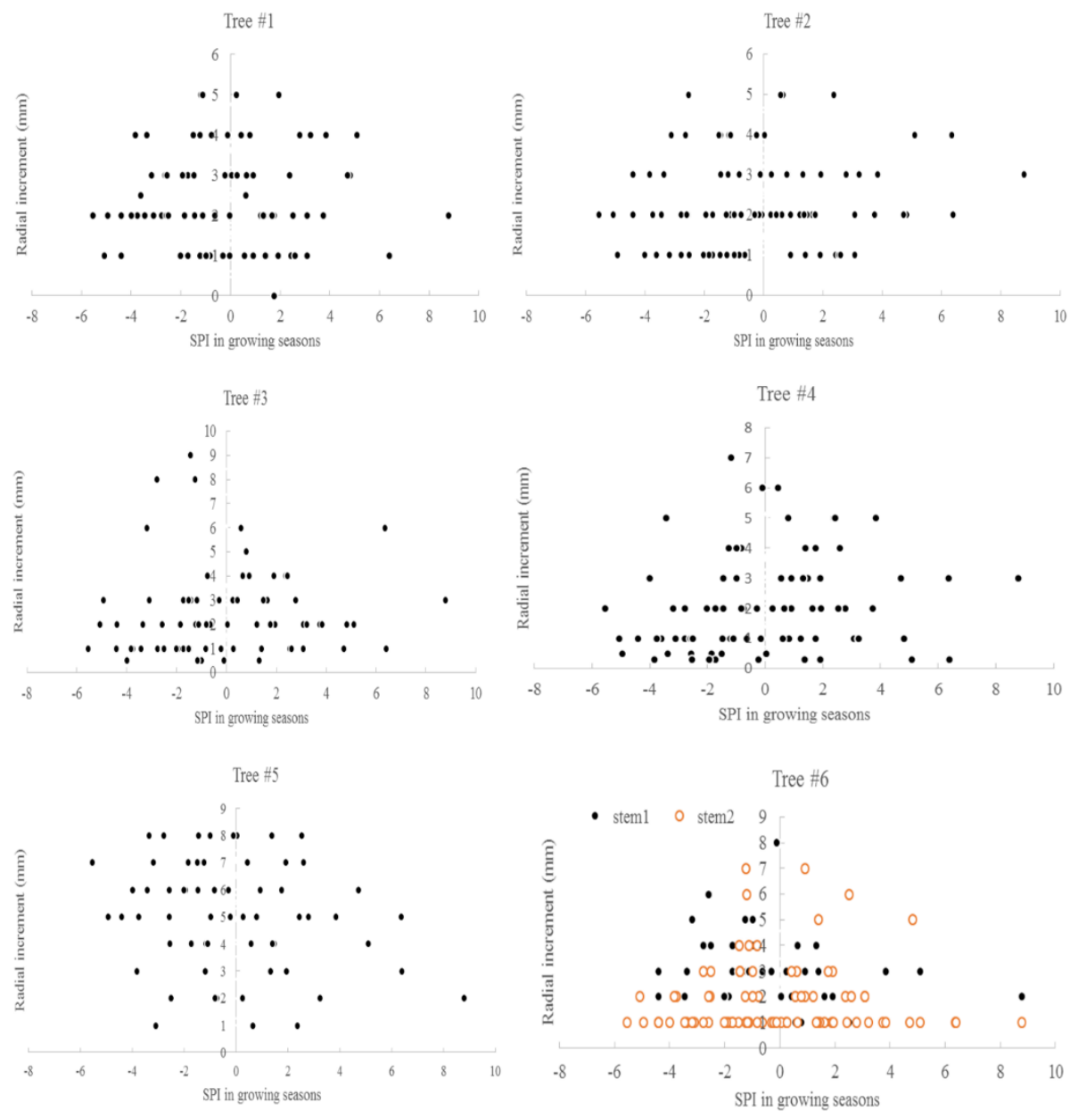

Figure 7. Standardized precipitation indices and annual radial increments for six Chinese Torreya trees.

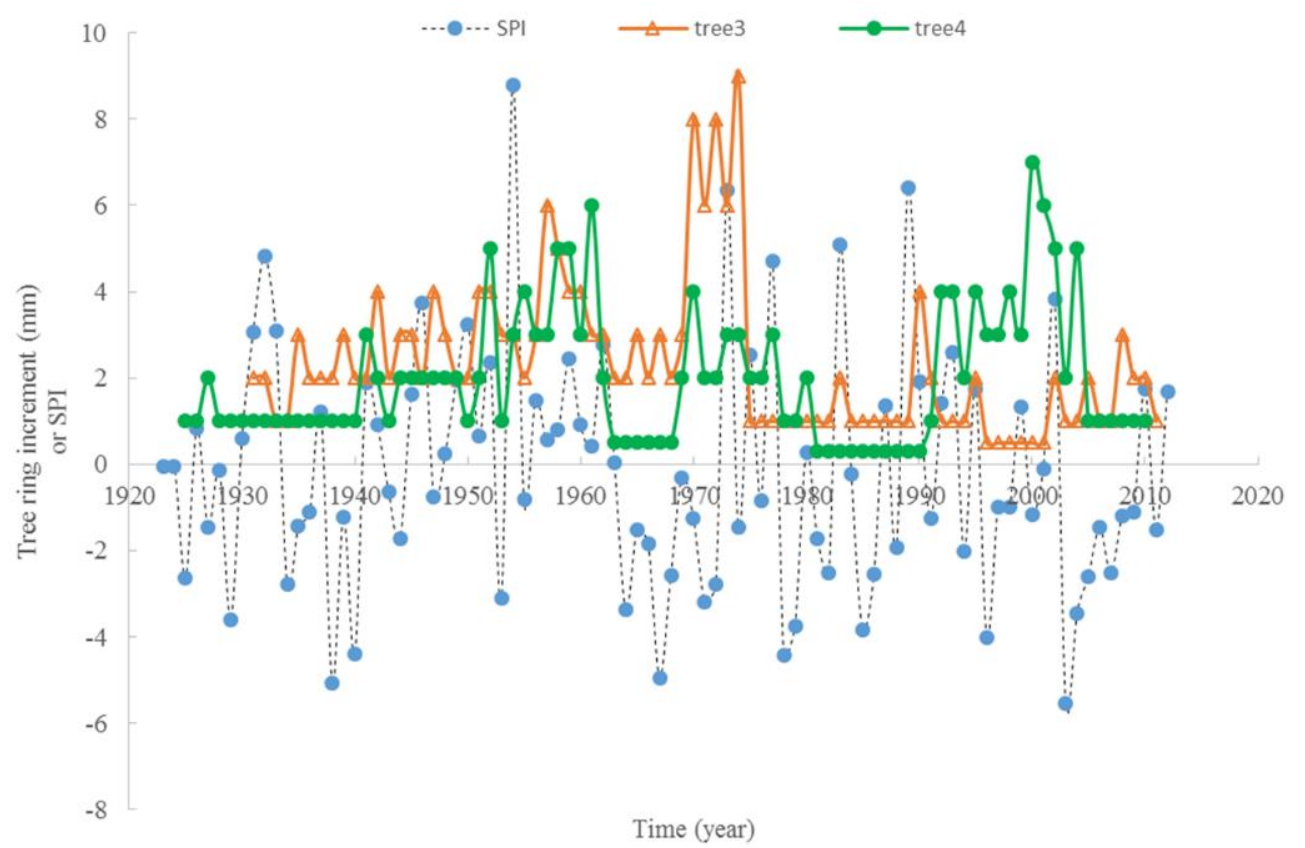

Figure 8. Response of tree ring increment to SPI change with time, for tree \#3 and \#4 (no negative values for tree ring increment). 

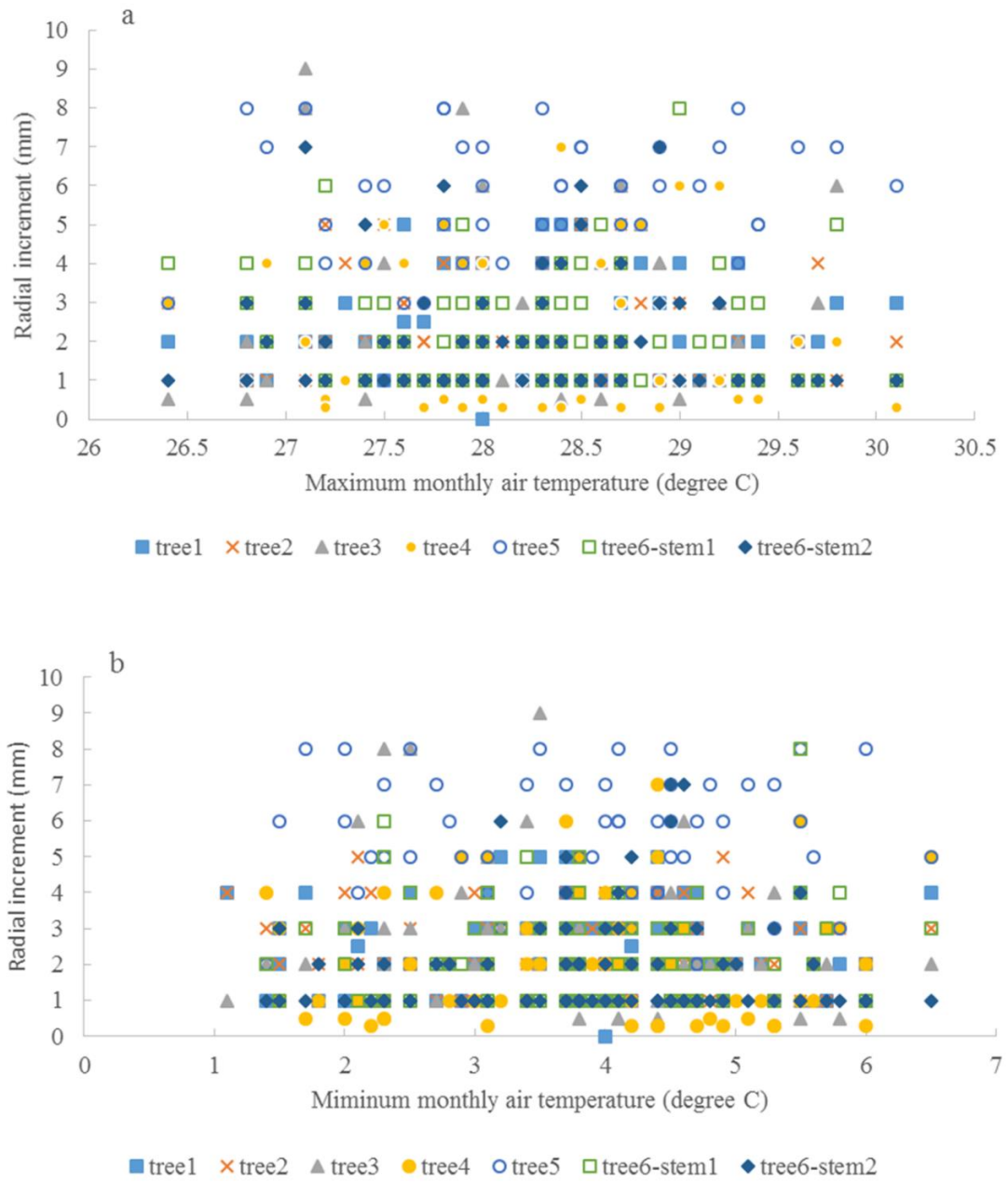

Figure 9. Maximum monthly air temperature and annual radial increments (a), and minimum monthly air temperature and annual radial increments $(\mathbf{b})$.
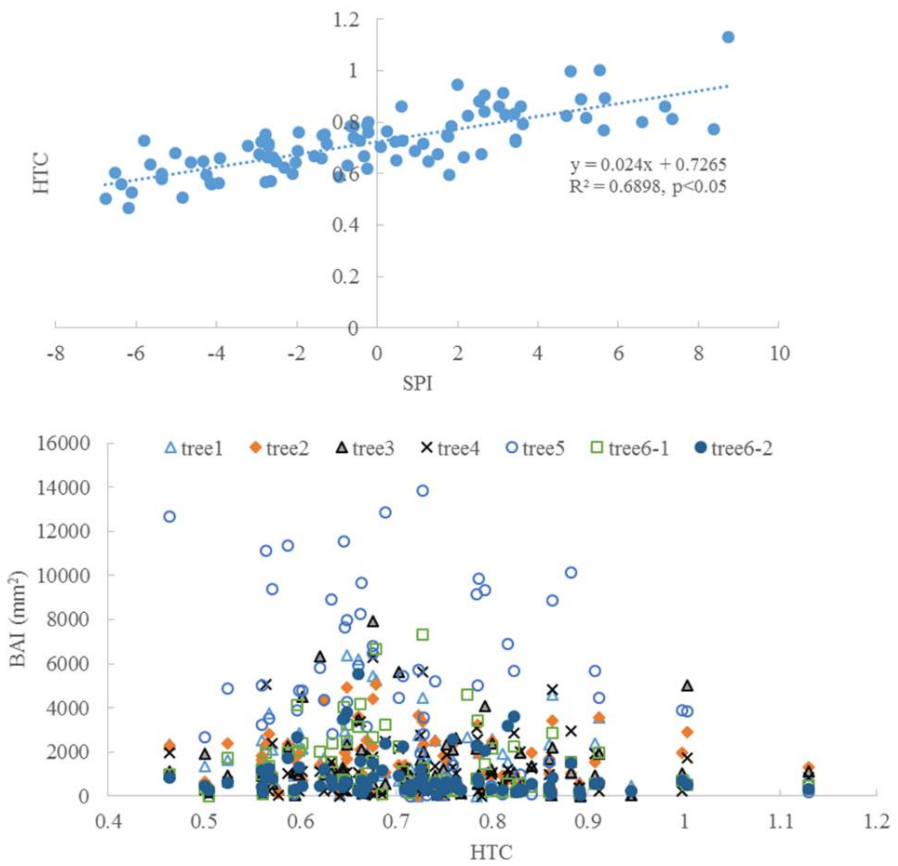

Figure 10. The correlation between SPI and HTC and the change of BAI along with HTC. 


\section{Discussion}

The dendrochronological data of six trees indicated that the accumulated radial growth increased with time in these Chinese Torreya trees when they were cut. This result means that these trees were not at the senescent age [47]. Usually, the life span of this tree can reach hundreds of years, or even more. Currently, the oldest in the region is approximately 1300 years old [13]. This result provided more evidence that slow-growth trees were associated with long life spans [48]. The long life span is advantageous for this tree species, as it helps create a long-term income from the seeds. Further, the slow growth and long life span of the species make it suitable for carbon sequestration. Other tree species grow fast but die young, so the periods over which they store carbon are short [49].

Taylor's power law can be observed in the accumulated radial growth, and the scaling exponents concentrated at 1.9-2.1, although the rates of accumulated radial growth varied among these trees. This means that the radial growth of these trees was under a similar regime (e.g., the same area with similar biological and environmental interactions) [50]. The historical climate dynamics did not constitute a significant regime shift in the radial growth for these trees. This study also confirmed the high tolerance of this tree species [11], that is, Tree \#3 and \#4 could endure limited radial growth for about 10 years. The slopes of the accumulated radial growth with time are significantly correlated with the scaling exponents of Taylor's power law. Both these slopes may reflect the biological and environmental interactions (e.g., self-organization) of these trees. Most annual radial increments were approximately 1 or $2 \mathrm{~mm} /$ year in these trees. The average annual radial increment of these trees was above $2 \mathrm{~mm} /$ year, and tree \#5 even reached $5 \mathrm{~mm} /$ year. This rate is considerably larger than the original reported value, of $1.1 \mathrm{~mm} /$ year, from a 1500-year-old tree by the Beijing Natural History Museum in 2012 [17]. These different rates and lasting times might be linked to small-scale local environmental conditions that support individual trees. However, the growth rates found here are still very low compared to those of other trees, such as loblolly pine in southeastern USA, which can reach $12 \mathrm{~mm} /$ year [51]. Thus, the first assumption of the slow growth rate being related to adaptation to the environment is valid.

Despite the approximate increase of $70 \mathrm{ppm}$ in global average $\mathrm{CO}_{2}$ concentration (increased from $315 \mathrm{ppm}$ to $390 \mathrm{ppm}$ from the $1920 \mathrm{~s}$ to 2015$)$, and the increase of approximately $2.5^{\circ} \mathrm{C}$ in the local annual air temperature [11], there was no clear trend of increasing radial increment in these trees. Furthermore, the variance in the radial increment did not increase for all individual trees. However, the variance of BAI generally increased for all trees. The second assumption related to the increase of variance is valid for BAI; it is more accurate for describing tree growth than radial increment, because the same radial increment can indicate a different BAI if the radiating rings are different. For some trees, there was a significant correlation between the variance of growing season precipitation and the variance of BAI (Figure 11). The variance of growing season precipitation explains about $40-66 \%$ of the variance of BAI. The $\mathrm{CO}_{2}$ fertilization effect might be counterbalanced by other environmental stressors, such as light condition, insufficient precipitation, and extremely high or low air temperature [52]. Different from [44], the tree ring widths here were not correlated with the annual rainfall.

There were "triangle"-shaped relationships between the annual radial increments and climate factors, such as the precipitation in growing seasons, the maximum monthly air temperature, and the minimum monthly air temperature in winter. This result means that tree growth was limited by many factors. The outlier points can be fitted by polynomials with a power of 2 . The optimum values of these factors were found in this study: the optimum precipitation during the growing seasons was approximately $975 \mathrm{~mm}( \pm 200 \mathrm{~mm})$, SPI was between -2 and 2, the maximum monthly air temperature was about $27.5-28.5^{\circ} \mathrm{C}$, the minimum monthly air temperature in winter was around $3-4{ }^{\circ} \mathrm{C}$, and HTC was approximately $0.7-0.9$. A climate within these limits may be better for growing Chinese Torreya trees. Climate conditions that are too dry, too wet, too warm or too cold may affect the radial increments of Chinese Torreya, which are believed to be linked with seed production. The trees could also tolerate a drought condition, with SPI around -6, or HTC of 0.46 in the growing seasons. This climate envelope may help in finding suitable areas to introduce Chinese Torreya into for industrial 
plantations. The result also provides a base for the agricultural insurance policy in this region. If trees cannot produce a normal amount of seeds under unfavorable weather conditions, then an agricultural insurance company will make a specific payment to the farmers to cover the loss. This result is different from [44], wherein rainfall augmented tree ring width, and hot temperature reduced tree ring growth in Scutia buxifolia. A positive correlation with precipitation, and a negative correlation with extreme summer temperatures, were usually observed for trees in Africa and Australia [53,54]. However, growth ceased at a certain threshold, rather than showing a continuous linear decline, was also observed in ponderosa pine [55].

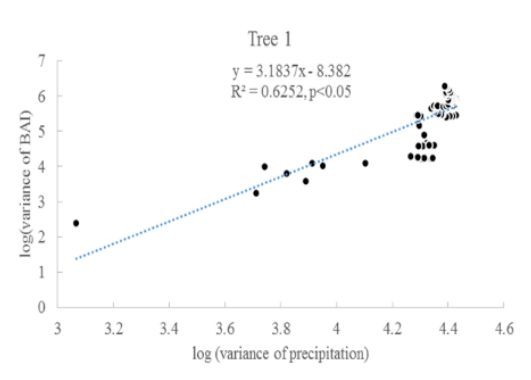

Tree 3

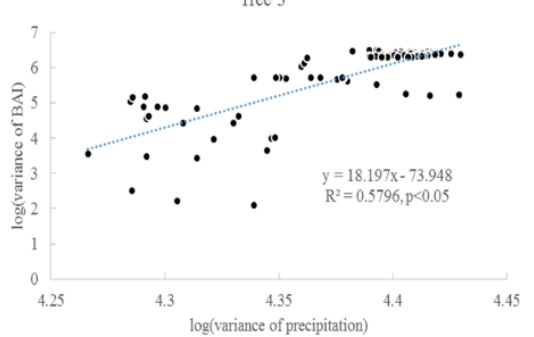

Tree 5

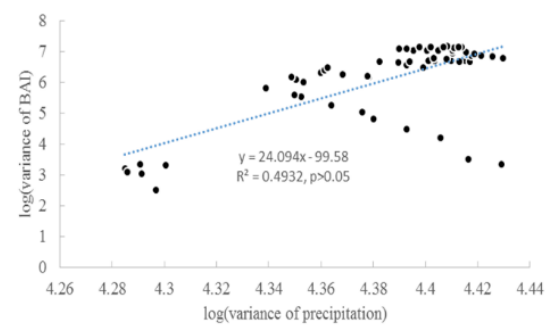

Tree 6-stem 2

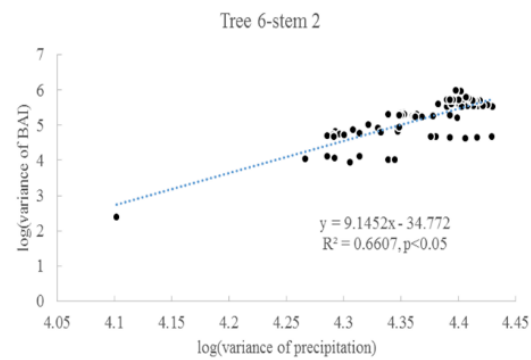

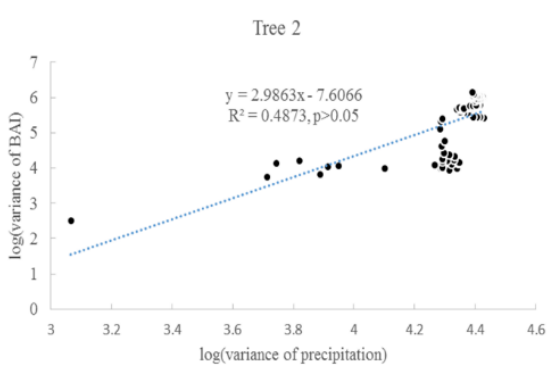

Tree 4

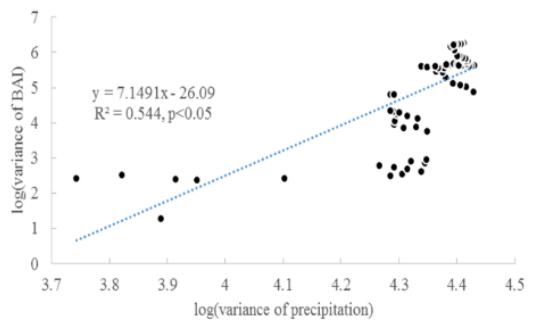

Tree 6- steml

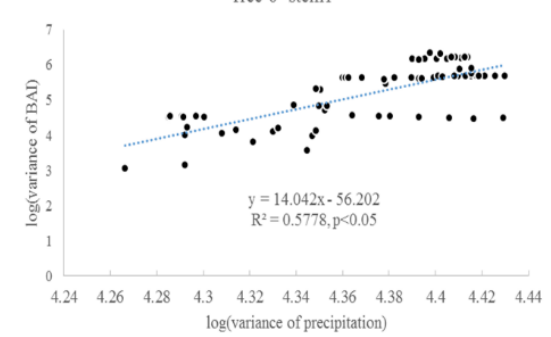

$\log ($ variance of precipitation)

Figure 11. Correlation between BAI variances and the variances of precipitation in the growing seasons for six Chinese Torreya trees.

The phenomenon of multiple stems living on one tree is very popular in Chinese Torreya. In this study, it was found that (i) the two stems had quite different radial increment rates; (ii) the two stems shared a similar growth regime (e.g., similar scaling exponents in Tayler's power law); and (iii) the two stems had different climate adaptations (e.g., dry or wet climate). The heterogeneous growth rates might be related to different positions, or the adaptation to different microclimate conditions. The phenomena may show the ability of an individual tree to achieve maximum growth under different 
environmental conditions. Morphological changes in trees are an adaptation strategy to climate change [56]. A tree with multiple stems may have the advantage of using solar radiation at different positions, and maintaining productivity under environmental variation, over a tree with a single stem. It is not known whether more stems is always better. However, Chinese Torreya trees with a couple of stems are popular in the central production area. Usually, a tree with multiple stems may have a big canopy, which may be easily damaged by typhoons.

This study provides several implications for the adaptive management of Chinese Torreya plantations. First, these trees still had radial growth at the age of 90 years. Since the life span of this tree species could reach a thousand years, it indicated that these trees were still at the early growth stage, which means Chinese Torreya trees can lead to long-term economic and biological income. However, the farmers still need to wait for 5-10 years for seedlings to produce the first seeds. Second, the timber growth rate of most trees was slow. However, some trees could have a relatively high growth rate, such as tree \#5. This result might be related to a genetic mutation or suitable local environmental setting (e.g., soil, water). This deviation makes it possible to identify the fast-growing tree varieties or select appropriate sites for a plantation. Regular citizen science or community activities may help select the variety with a high timber or seed production. Local citizen scientists should be trained to preserve genetic variations and other natural resources that are particularly adapted to climate change [12]. Some trees grow slowly, but may have a high endurance to climate change. Third, selecting trees with multiple stems in plantations may offer the advantage of maintaining productivity under environmental change. The stems can take advantage of the light at different positions, and adapt to different conditions. Fourth, the effect of climate change on tree growth could be estimated via precipitation in growing seasons, and the highest or the lowest monthly air temperature. Further, the climate conditions identified by this study may be useful for introducing Chinese Torreya trees to new locations. Besides, human management practices, such as cutting grasses and shrubs and digging surface soil, could alter tree growth through the changing soil water and air temperature. However, these management practices may not be a good way to maintain proper environmental conditions at certain stages, and may lead to environmental problems [12,39,40]. Finally, based on the radial growth patterns, it is possible to estimate the tree canopy size and possible seed production through allometric scaling relationships $[49,57,58]$. This algorithm may help forest farmers assess potential income and benefits, and also helps them manage Chinese Torreya plantations more effectively.

\section{Conclusions}

Chinese Torreya is an important crop tree with a long life span. The dendrochronological data of Chinese Torreya trees are very scarce. This study is the first one that provides relevant information for understanding growth patterns and the adaptation of this tree to climate dynamics. In this central production area, the long-term persistence of Chinese Torreya could indicate its adaptation to the historical climate fluctuation and atmospheric $\mathrm{CO}_{2}$ enrichment. The slow radial growth rate of Chinese Torreya (on average, form 1.9 to $5.1 \mathrm{~mm} /$ year) might help this species to adapt to unfavorable conditions. The change of precipitation in growing seasons could impact the variation of basal area increment. The radial growth regime did not change significantly during their life spans, because similar Taylor's power law exponents existed in the accumulated radial growths. "Triangle"-shaped relationships, which indicate optimum values, occurred between the climate and annual radial increments, especially the extreme air temperature (maximum and minimum monthly air temperatures), precipitation in growing seasons, and drought, which could affect its growth rate as well as the variance. The trees could tolerate the drought conditions with SPI of approximately -6 , or HTC of 0.46 in growing seasons, and being either too dry or too wet both decreased tree growth. The presence of multiple stems in one tree could help it adapt more effectively to the local environment. It is necessary to conduct long-term intensive monitoring projects across different environmental settings, which can help in collecting data to find the relationships between tree growth and environmental change. It will be helpful to derive the core increment data from some old trees, although this may affect these trees. 
However, these long dendrochronological data could provide beneficial information about adaptive response and endurance. Local agencies need to organize citizen scientists to collect sample trees and preserve genetic diversity, since some trees (e.g., tree \#5) could grow much faster, which may provide the opportunity for developing fast-growing trees. In contrast, other trees (e.g., tree \#4) might have high endurance. The current introduction of this tree to new areas for plantation should be based on the environmental requirements. Regional planners and decision-makers need to know the tree growth ecology, and consider the possible unfavorable environmental conditions, before introducing or developing large-scale plantations of Chinese Torreya.

Funding: This study was partially supported by the USDA Mc-Stennis project (1008643).

Acknowledgments: The author thanks anonymous reviewers and Troy Bowman for their helpful suggestions. Hangbiao Jin and Jinchang Li from Zhuji Forestry Academy provided relevant information, and Xi Chen assisted in measurements.

Conflicts of Interest: The author declares no conflict of interest.

\section{References}

1. Pretzsch, H.; Biber, P.; Schütze, G.; Uhl, E.; Rötzer, T. Forest stand growth dynamics in Central Europe have accelerated since 1870. Nat. Commun. 2014, 5, 4967. [CrossRef]

2. Brandl, S.; Paul, C.; Knoke, T.; Falk, W. The influence of climate and management on survival probability for Germany's most important tree species. For. Ecol. Manag. 2020, 458, 117652. [CrossRef]

3. Vossen, P. Olive oil: History, production, and characteristics of the world's classic oils. HortScience 2007, 42, 1093-1100. [CrossRef]

4. Seidl, R.; Schelhaas, M.-J.; Rammer, W.; Verkerk, P.J. Increasing forest disturbances in Europe and their impact on carbon storage. Nat. Clim. Chang. 2014, 4, 806-810. [CrossRef] [PubMed]

5. Chapman, S.C.; Chakraborty, S.; Dreccer, M.F.; Howden, S.M. Plant adaptation to climate change-opportunities and priorities in breeding. Crop. Pasture Sci. 2012, 63, 251-268. [CrossRef]

6. van der Sleen, P.; Groenendijk, P.; Vlam, M.; Anten, N.P.R.; Boom, A.; Bongers, F.; Pons, T.L.; Terburg, G.; Zuidema, P.A. No growth stimulation of tropical trees by 150 years of $\mathrm{CO}_{2}$ fertilization but water-use efficiency increased. Nat. Geosci. 2014, 8, 4. [CrossRef]

7. Maryinez-Feria, R.A.; Basso, B. Unstable crop yields reveal opportunities for site-specific adaptations to climate variability. Sci. Rep. 2020, 10, 2885. [CrossRef]

8. Chen, X.; Brockway, D.G.; Guo, Q. Characterizing the dynamics of cone production for longleaf pine forests in the southeastern United States. For. Ecol. Manag. 2018, 429, 1-6. [CrossRef]

9. Lobell, D.B.; Burke, M.B.; Telbaldi, C.; Mastrandrea, M.D.; Falcon, W.P.; Naylor, R.L. Prioritizing climate change adaptation needs for food security in 2030. Science 2008, 319, 607-610. [CrossRef]

10. Hammer, G.L.; McLean, G.; Chapman, S.; Zheng, B.; Doherty, A.; Harrison, M.T.; van Oosterom, E.; Jordan, D. Crop design for specific adaptation in variable dryland production environments. Crop. Pasture Sci. 2014, 65, 614-626. [CrossRef]

11. Chen, X.; Niu, J. Evaluating the adaptation of Chinese Torreya plantations to climate change. Atmosphere 2020, 11, 176. [CrossRef]

12. Chen, X.; Jin, H. Review of cultivation and development of Chinese torreya in China. For. Trees Liveli. 2019, 28, 68-78. [CrossRef]

13. Li, Z.; Dai, W. Chinese Torreya; Science Press: Beijing, China, 2007. (in Chinese)

14. Roy, D.F. Torreya Arn. Torreya. In Seeds of Woody Plants in the United States; Schopmeyer, C.S., Ed.; Agriculture Handbook No. 450 USDA Forest Service: Washington, DC, USA, 1974.

15. Shin, S.; Lee, S.G.; Kang, H. Spatial distribution patterns of old-growth forest of dioecious tree Torreya nucifera in rocky Gotjawal terrain of Jeju Island, South Korea. J. Ecol. Environ. 2017, 41, 31. [CrossRef]

16. Farjon, A. A Handbook of the World's Conifers; Brill Academic Publishing: Leiden, Netherlands, 2010.

17. Wang, B.; Ming, Q.-W. Zhejiang Shaoxing Kuaijishan Guxiangfeiqun; China Agricultural Press: Beijing, China, 2015. (in Chinese)

18. Hu, H.-H. Synoptical study of Chinese Torreyas: With supplemental notes on the distribution and habitat by R. C. Ching. Contrib. Biol. Lab. Sci. Soc. China 1927, 3, 1-37. 
19. Cheng, X.; Li, Z.; Yu, W.; Dai, W.; Fu, Q. Distribution and ecological characteristics of Torreya grandis in China. J. Zhejiang For. Coll. 2007, 24, 383-388, (in Chinese with English abstract).

20. Chen, X.; Jin, H. A case study of enhancing sustainable intensification of Chinese torreya forest in Zhuji of China. Environ. Nat. Res. Res. 2019, 9, 53-60. [CrossRef]

21. People's Government of Shaoxing City. Kuanjishan Ancient Chinese Torreya Community; Proposal for Global Important Agricultural Heritage System Initiative: Shaoxing, China, 2013.

22. Chen, X.; Chen, H. Dynamics in production of four heritage foods at the mountainous region of Shaoxing City, China. Emir. J. Food Agric. 2019, 31, 645-653. [CrossRef]

23. Huang, Y.; Wang, J.; Li, G.; Zheng, Z.; Su, W. Antitumor and antifungal activities in endophytic fungi isolated from pharmaceutical plants Taxus mairei, Cephalataxus fortunei and Torreya grandis. FEMS Immunol. Med. Microbiol. 2001, 31, 163-167. [CrossRef]

24. Chen, X.; Zhang, X.; Li, B.-L. The possible response of life zones in China under global climate change. Glob. Planet. Chang. 2003, 38, 323-337. [CrossRef]

25. Li, T.; Hu, Y.; Du, X.; Tang, H.; Shen, C.; Wu, J. Salicylic acid alleviates the adverse effects of salt stress in Torreya grandis cv. Merrillii seedlings by activating photosynthesis and enhancing antioxidant systems. PLoS ONE 2014, 9, e109492. [CrossRef]

26. Lin, J.; Zhang, R.; Hu, Y.; Song, Y.; Hanninen, H.; Wu, J. Interactive effects of drought and shading on Torreya grandis seedlings: Physiological and growth responses. Trees 2019, 33, 951-961. [CrossRef]

27. Wang, Z.; Xu, W.-Z. Seedling cultivation of Chinese Torreya and observation on height growth in one-year-old seelings. Appl. For. Tech. 2006, 4, 18-19. (in Chinese).

28. Boden, S.; Kahle, H.P.; Wilpert, K.V.; Spiecker, H. Resilience of Norway spruce (Picea abies (L.) Karst) growth to changing climatic conditions in Southwest Germany. For. Ecol. Manag. 2014, 315, 12-21. [CrossRef]

29. Costa, M.S.; Ferreira, K.E.B.; Botosso, P.C.; Callado, C.H. Growth analysis of five Leguminosae native tree species from a seasonal semidecidual lowland forest in Brazil. Dendrochronologia 2015, 36, 23-32. [CrossRef]

30. Worbes, M.; Staschel, R.; Roloff, A.; Junk, W.J. Tree ring analysis reveals age structure, dynamics and wood production of a natural forest stand in Cameroon. For. Ecol. Manag. 2003, 173, 105-123. [CrossRef]

31. Mbow, C.; Chhin, S.; Sambou, B.; Skole, D. Potential of dendrochronology to assess annual rates of biomass productivity in savanna trees of West Africa. Dendrochronologia 2012, 31, 41-51. [CrossRef]

32. Shimamoto, C.Y.; Botosso, P.C.; Marques, M.C.M. How much carbon is sequestered during the restoration of tropical forests? Estimates from tree species in the Brazilian Atlantic Forest. For. Ecol. Manag. 2014, 329, 1-9. [CrossRef]

33. Granato-Souza, D.; Adenesky-Filho, E.; Esemann-Quadros, K. Dendrochronology and climatic signals in the wood of Nectandra oppositifolia from a dense rain forest in southern Brazil. J. For. Res. 2018, 30, 545-553. [CrossRef]

34. Natalini, F.; Correia, A.C.; Vazquez-Pique, J.; Alejano, R. Tree rings reflect growth adjustments and enhanced synchrony among sites in Iberian stone pine (Pinus pinea L.) under climate change. Ann. For. Sci. 2015, 72, 1023-1033. [CrossRef]

35. Prestes, A.; Klausner, V.; Silva, I.R.; Ojeda-Gonzalez, A.; Lorensi, C. Araucaria growth response to solar and climate variability in South Brazil. Ann. Geophys. Dis. 2018, 36, 717-719. [CrossRef]

36. Rahman, M.; Islam, R.; Islam, M. Long-term growth decline in Toona ciliata in a moist tropical forest in Bangladesh: Impact of global warming. Acta Oecol. 2017, 80, 8-17. [CrossRef]

37. Allen, C.D.; Breshears, D.D.; McDowell, N.G. On underestimation of global vulnerability to tree mortality and forest die-off from hotter drought in the Anthropocene. Ecosphere 2015, 6, 1-55. [CrossRef]

38. Corlett, R.T. The impacts of droughts in tropical forests. Trends Plant. Sci. 2016, 21, 584-593. [CrossRef] [PubMed]

39. Chen, X.; Chen, H. Comparing environmental impacts of Chinese Torreya plantations and regular forests using remote sensing. Environ. Dev. Sustain. 2020, in press. [CrossRef]

40. Chen, X.; Xiao, P.; Niu, J.; Chen, X. Evaluating soil and nutrients (C, N, and P) loss in Chinese Torreya plantations. Environ. Pollut. 2020, in press. [CrossRef]

41. Pearse, I.S.; LaMontagne, J.M.; Koenig, W.D. Inter-annual variation in seed production has increased over time (1900-2014). Proc. Royal Soc. B 2017, 284, 20171666. [CrossRef]

42. Taylor, L.R. Aggregation, variance and the mean. Nature 1961, 189, 732-735. [CrossRef] 
43. Harris, I.; Jones, P.D.; Osborn, T.J.; Lister, D.H. Updated high-resolution grids of monthly climatic observations-The CRU TS3.10 Dataset. Int. J. Climatol. 2014, 34, 623-642. [CrossRef]

44. Lucas, C.; Puchi, P.; Profumo, L.; Ferreira, A.; Muñoz, A. Effect of climate on tree growth in the Pampa biome of Southeastern South America: First tree-ring chronologies from Uruguay. Dendrochronologia 2018, 52, 113-122. [CrossRef]

45. McKee, T.B.; Doesken, N.J.; Kliest, J. The relationship of drought frequency and duration to time scales. In Proceedings of the 8th Conference of Applied Climatology, Anaheim, CA, USA, 17-22 January 1993; American Meteorological Society: Boston, MA, USA, 1993; pp. 179-184.

46. Evarte-Bundere, G.; Evarts-Bunders, P. Using of the hydrothermal coefficient (HTC) for interpretation of distribution of non-native tree species in Latvia on example of cultivated species of genus Tilia. Acta Biol. Univ. Daugavp. 2012, 12, 135-148.

47. Fritts, H. Tree Rings and Climate; Academic: San Diego, CA, USA, 1976.

48. Black, B.A.; Colbert, J.J.; Pederson, N. Relationships between radial growth rates and lifespan within North American tree species. Ecoscience 2008, 15, 349-357. [CrossRef]

49. Chen, X. Carbon storage traits of main tree species in natural forests in Northeast China. J. Sustain. For. 2006, 23, 67-84. [CrossRef]

50. Chen, X.; Guo, Q.; Brockway, D.G. Power laws in cone production of longleaf pine across its native range in the United States. Sustain. Agric. Res. 2017, 4, 64-73. [CrossRef]

51. Chen, $X$. Will more tree diversity bring back more income from timber? A case study from Alabama of USA. For. Lett. 2017, 110, 20-25.

52. Wagner, F.H.; Hérault, B.; Bonal, D.; Stahl, C.; Anderson, L.O.; Baker, T.R.; Becker, G.S.; Beeckman, H.; Boanerges, S.D.; Botosso, P.C.; et al. Climate seasonality limits leaf carbon assimilation and wood productivity in tropical forests. Biogeosciences 2016, 13, 2537-2562. [CrossRef]

53. Baker, P.J.; Palmer, J.G.; D'Arrigo, R. The dendrochronology of Callitris intratropica in northern Australia: Annual ring structure, chronology development and climate correlations. Aust. J. Bot. 2008, 56, 311-320. [CrossRef]

54. Trouet, V.; Coppin, P.; Beeckman, H. Annual growth ring patterns in Brachystegia spiciformis reveal influence of precipitation on tree growth. Biotropica 2006, 38, 375-382. [CrossRef]

55. McCullough, I.M.; Davis, F.W.; Williams, A.P. A range of possibilities: Assessing geographic variation in climate sensitivity of ponderosa pine using tree rings. For. Ecol. Manag. 2017, 402, 223-233. [CrossRef]

56. McDowell, N.G.; Allen, C.D.; Anderson-Teixeira, K.; Bond-Lamberty, B.; Chini, L.; Clark, J.S.; Dietze, M.; Grossiord, C.; Hanbury-Brown, A.; Hurt, G.C.; et al. Pervasive shifts in forest dynamics in a changing world. Science 2020, 368, eaaz9463. [CrossRef]

57. Chen, X. Diverse scaling relationships of tree height and diameter in five tree species. Plant. Ecol. Divers. 2018, 11, 147-155. [CrossRef]

58. Chen, X.; Chen, H. Analyzing patterns of seed production for Chinese Torreya. HortScience 2020, 55, 778-786. [CrossRef]

(C) 2020 by the author. Licensee MDPI, Basel, Switzerland. This article is an open access article distributed under the terms and conditions of the Creative Commons Attribution (CC BY) license (http://creativecommons.org/licenses/by/4.0/). 